\title{
Comparison of HbA1c Levels in Patients With TB-DM And TB-non DM
}

\author{
Nona Rahmaida Puetri, Zain Hadifah, Abidah Nur, Sari Hanum \\ Health Research and Development Office, Banda Aceh, Indonesia
}

\begin{abstract}
Tuberculosis (TB) is still a global problem that has not currently been resolved, due to it rapid transmission through droplet nuclei released when TB patients cough, sneeze, or even talking. One of the TB comorbidities is diabetes mellitus (DM) that makes it necessary to do HbA1c screening in patients with TB DM and TB non-DM to prevent further disease complications. This was a cross-sectional descriptive analytic study conducted in 2018 on a total sample of 248 TB-DM and TB non-DM patients in Aceh Besar District and Banda Aceh City, Indonesia with $29.8 \%$ of the subjects were TB-DM patients and the remaining $70.2 \%$ were TB Non-DM patients. The HbA1c levels in TB patients varied, with the average HbA1c level of $10.738 \%$ in people with TB DM and 5.426\% in TB non-DM. The HbA1c level in patients with TB DM was two times higher than in TB non-DM patients. It was found that $21.6 \%$ of TB patients who were not diagnosed with DM had HbA1c levels above $6.5 \%$. It is recommended that TB sufferers do HbA1c screening to prevent DM complications.
\end{abstract}

Key words: HbA1c, tuberculosis, TB DM, Non-DM TB

\section{Perbandingan Kadar HbA1c Pasien TB DM dan TB Tanpa DM}

\begin{abstract}
Abstrak
Tuberkulosis (TB) masih merupakan permasalahan global yang belum tuntas hingga saat ini, hal tersebut karena penularannya yang sangat cepat melalui percik renik dahak yang dikeluarkan pada saat penderita TB batuk atau bersin bahkan saat berbicara. Salah satu penyakit penyerta TB adalah diabetes militus (DM), maka perlu dilakukan screening HbA1c (hemoglobin A1c) terhadap pasien TB DM maupun TB tanpa DM untuk mencegah komplikasi lebih lanjut. Penelitian ini menggunakan metode cross sectional dengan deskriptif analitik. Penelitian ini dilaksanakan tahun 2018 dengan jumlah sampel 248 di wilayah Kabupaten Aceh Besar dan Kota Banda Aceh. Hasil penelitian menunjukkan jumlah pasien TB DM 29,8\% dan TB tanpa DM 70,2\%. Penderita TB DM terbanyak adalah laki-laki (71\%). Kadar HbA1c pada penderita TB bervariasi, rata-rata pada pasien TB DM adalah 10,738\% dan TB tanpa DM 5,426\%. Kadar HbA1c pasien TB DM dua kali lebih besar dibanding dengan TB tanpa DM. Ditemukan 21,6\% penderita TB yang tidak terdiagnosa DM memiliki kadar HbA1c diatas 6,5\%. Maka disarankan penderita TB melakukan screening HbA1c untuk mencegah komplikasi DM.
\end{abstract}

Kata kunci: HbA1c, tuberkulosis, TB DM, TB tanpa DM

Corresponding Author: Nona Rahmaida Puetri, Health Research and Development Office, Banda Aceh, Jl. Bandara Internasional Sultan Iskandar Muda Blang Bintang, Lr. Biomedis No. 9, Kabupaten Aceh Besar, Indonesia, Email: nona. rahmaidapuetri@gmail.com 


\section{Introduction}

Tuberculosis (TB) is still one of the top 10 causes of death from infectious diseases in the world, with estimated 1.3 million people die each year from this disease. ${ }^{1}$ The number of new TB cases globally is 6.3 million, while in Indonesia alone the number of new cases in 2017 was 425,089 cases with 7,342 cases was found in Aceh. ${ }^{2,3}$ Tuberculosis is caused by bacteria from Mycobacterium tuberculosis species. Currently, there are several diseases that are known to be present together with tuberculosis, one of which is diabetes mellitus (DM). DM itself is a non-infectious disease characterized by an increase in blood glucose level (hyperglycemia) that disrupts carbohydrate, fat, and protein metabolism which causes the pancreas to not produce enough insulin to act as a hormone that regulates blood glucose balance. ${ }^{4-6}$ According to the International Diabetes Federation (IDF) in 2017, the number of DM patients in the world has reached 425 million and it is predicted that this number will increase by $48 \%$ and will reach 629 million by 2045. In 2017, it was estimated that there were 10 million people suffer from DM in Indonesia, making the country ranks 6th in the number of diabetes cases in the world. ${ }^{5}$ Currently, the national prevalence for diabetes is $1.5 \%$ while in Aceh Province the prevalence is higher than the national level. ${ }^{7}$

One of the targets of the Sustainable Development Goals (SDGs) is to end the TB epidemic in 2030 with the prevalence of diabetes as one of the indicators. ${ }^{1}$ Diabetes is an important risk factor in the development of Active TB because TB patients with comorbid DM have a risk of 3 (three) times higher to suffer from active TB and TB-DM patient treatment often fails and even tend to have high potential for the incidence of MDR. DM in TB can be the underlying cause of MDR TB due to the difficulty in controlling blood glucose that will affect the healing process of TB. Several DM drugs inhibit certain types of TB drugs that the effectiveness of the drug is reduced. As a result of suboptimal drug absorption, TB may recur and lead to $\mathrm{MDR}^{4,8}$ especially against line 1 Anti Tuberculosis drugs (ATD) such as rifampicin and isoniazid. ${ }^{9}$ DM diagnosis can be performed in two ways: blood glucose level testing and HbA1c level testing. ${ }^{6}$ HbA1c is a minor component of hemoglobin that binds to glucose with a recommended cut off point for diabetes of $\geq 6.5 \%{ }^{10}$

There is no study on HbA1c levels in TB patients in Aceh Besar District and Banda Aceh
City that has been widely reported. This study aimed to determine the HbA1c levels of TB patients diagnosed with DM and TB patients who have not been diagnosed with DM. It is expected that the results of this study can provide screening information for patients with undiagnosed TB but have an HbA1C level that matches the DM category. This knowledge can provide input to the programs related to effective and efficient TB-DM treatment for TB-DM patients in Banda Aceh City and Aceh Besar District that can be considered by the stakeholders. Effective and efficient programs are important on the basis of the number of TB-DM cases in these areas.

\section{Methods}

This was a cross-sectional study that made use of data on pulmonary tuberculosis treatment from hospitals and public health centers in Banda Aceh city and Aceh Besar district during 2018. All pulmonary tuberculosis patients were screened for DM by measuring the HbA1c level. The inclusion criteria for this study were pulmonary tuberculosis patients who were recorded in hospitals and public health centers in Banda Aceh City and Aceh Besar District. TB diagnose based on the results of the doctor's diagnosis and also the results of laboratory microscopic slides at the first level health facility (FKTP); patients under treatment for pulmonary tuberculosis; aged $\geq 15$ years, and did not suffer from blood clotting abnormalities. Exclusion criterion was patients suffering from a severe illness and communication disorders.

This study followed the subject recruitment flow, based on the inclusion and exclusion criteria, All patients interviewed $(n=264)$, From the interviews, there were 262 patients suffering from pulmonary tuberculosis. All patients had unknown HbA1c levels. Furthermore, the results of the interview obtained two categories of patients, namely: TB DM totaling 74 people and TB Non DM totaling 174 people. Two groups of subjects were established: TB-DM group for subjects who had diabetes and TB Non-DM group for those who did not have diabetes or in the pre-diabetic stage. The HbA1c examination is carried out in a commercial laboratory that has been trusted in Aceh for the accuracy of the HbA1c examination. and for the level of difference categorized for diabetes was $\geq 6.5 \%$ and non-diabetics was $\leq 6.4 \%$. The analysis was univariate to show the percentage of the diabetic and non-diabetic groups, and bivariate analysis 
Table 1 Subject Characteristics

\begin{tabular}{|c|c|c|}
\hline Characteristic & Total $(n=248)$ & Percent (\%) \\
\hline \multicolumn{3}{|l|}{ Age } \\
\hline Mean \pm SD & $45,52 \pm 15,72$ & \\
\hline Productive $(\leq 64$ years $)$ & 217 & 87,5 \\
\hline Non productive ( $\geq 65$ years) & 31 & 12,5 \\
\hline \multicolumn{3}{|l|}{ Sex } \\
\hline Male & 167 & 67,3 \\
\hline Female & 81 & 32,7 \\
\hline \multicolumn{3}{|l|}{ Education } \\
\hline Never receive formal education & 13 & 5,2 \\
\hline Did finish Elementary School & 29 & 11,7 \\
\hline Elementary School & 56 & 22,6 \\
\hline Junior High School & 43 & 17,3 \\
\hline Senior High School & 84 & 33,9 \\
\hline Diploma/Bachelor & 23 & 9,3 \\
\hline
\end{tabular}

with chi square uses to find out the relationship between sex, education, age and history of DM

Ethical approval was obtained from the National Institute of Health Research and Development, Ministry of Health of the Republic of Indonesia with the issuance of the ethical clearance No: LB.02.01/2/KE.162/2018, dated April 30, 2018.

\section{Results}

The characteristics of the subjects in this study are presented in table 1 . Most of the subjects were in their productive age $(n=217,87.5 \%)$ with male subjects comprised the majority of the subjects (67.3\%). About $34 \%$ of the subjects graduated from Senior High School.

The results of $\mathrm{HbA} 1 \mathrm{c}$ testing are presented in figure with $28.9 \%$ of the subjects were categorized in the DM category. The average HbA1c level of TB DM subjects were two times

Table 2 HbA1c Levels in TB DM and TB NonDM Subjects

\begin{tabular}{lcc}
\hline \multirow{2}{*}{ Variable } & \multicolumn{2}{c}{ Category HbA1C } \\
\cline { 2 - 3 } & TB DM & TB non DM \\
\hline $\begin{array}{l}\text { Average HbA1C } \\
\text { levels (\%) } \\
\text { Total Patient }\end{array}$ & 10,738 & 5,426 \\
\hline
\end{tabular}

higher than the level in the TB non DM subjects (Table 2).

When subjects were analyzed by gender, it was revealed that male subjects comprised the majority of TB-DM cases $(n=54,32.3 \%)$ as listed in table 3 . It was also identified that $21.6 \%$ $(n=16)$ of the subjects were were not diagnosed as DM patients by the health care workers in the hospitals and public health centers (Table 4).

The results of bivariate analysis show that DM history has a relationship with $\mathrm{HbA1c}$ level (p-value $\leq 0.0001$ ) but sex, education and ages showed no relationship ( $p$-value $\geq 0,05$ ) (Table 5).

Table 3 HbA1c Level Category by Gender

\begin{tabular}{lcc}
\hline \multirow{2}{*}{ Variable } & \multicolumn{2}{c}{ Category HbA1C } \\
\cline { 2 - 3 } & TB DM & TB Non DM \\
\hline Men & $54(32.3 \%)$ & $113(67.7 \%)$ \\
Women & $20(24.7 \%)$ & $61(75.3 \%)$ \\
\hline
\end{tabular}

Table 4 HbA1c Category Based on DM Diagnosis by Health Care Workers (HCW)

\begin{tabular}{lcc}
\hline \multirow{2}{*}{ Variables } & \multicolumn{2}{c}{ in HbA1CCategory } \\
\cline { 2 - 3 } & TBDM & Non DM TB \\
\hline Yes & $58(78.4 \%)$ & $5(2.9 \%)$ \\
No & $16(21.6 \%)$ & $169(97.1 \%)$ \\
\hline
\end{tabular}


Table 5 Bivariate Analysis between Sex, Education, Age, and History of DM Variables

\begin{tabular}{|c|c|c|c|c|c|}
\hline \multirow[b]{2}{*}{ Variable } & \multicolumn{2}{|c|}{ HbA1c Level } & \multirow[b]{2}{*}{ OR } & \multirow[b]{2}{*}{ CI (95\%) } & \multirow[b]{2}{*}{ p-value } \\
\hline & $\begin{array}{c}\text { TB DM } \\
(\geq 6.5 \%)\end{array}$ & $\begin{array}{c}\text { TB non-DM } \\
(\leq 6.4 \%)\end{array}$ & & & \\
\hline \multicolumn{6}{|l|}{ Sex } \\
\hline Male & $54(73 \%)$ & $113(64.9 \%)$ & 1.458 & $0.800-2.656$ & 0.217 \\
\hline Female & $20(23 \%)$ & $61(35.1 \%)$ & & & \\
\hline \multicolumn{6}{|l|}{ Education } \\
\hline Never receive formal education & $4(5.4 \%)$ & $9(5.2 \%)$ & & & \\
\hline Did not finish Elementary School & $10(13.5 \%)$ & $19(10.9 \%)$ & 0.884 & $0.207-3.441$ & 0.814 \\
\hline Elementary School & $18(24.3 \%)$ & $38(21.8 \%)$ & 0.938 & $0.255-3.458$ & 0.924 \\
\hline Junior High School & $13(17.6 \%)$ & $30(17.2 \%)$ & 1.026 & $0.267-3.939$ & 0.971 \\
\hline Senior High School & $22(29.7 \%)$ & $62(35.6 \%)$ & 1.253 & $0.350-4.479$ & 0.729 \\
\hline Diploma/Bachelor & $7(9.5 \%)$ & $16(9.2 \%)$ & 1.016 & $0.232-4.441$ & 0.983 \\
\hline \multicolumn{6}{|l|}{ Age } \\
\hline Productive & $66(89.2 \%)$ & $151(86.8 \%)$ & 1.257 & $0.534-2.954$ & 0.6 \\
\hline Non productive & $8(10.8 \%)$ & $23(13.2 \%)$ & & & \\
\hline \multicolumn{6}{|l|}{ DM History } \\
\hline Yes & $58(78.4 \%)$ & $5(2.9 \%)$ & 122.525 & $42.982-349.274$ & $<0.0001$ \\
\hline No & $16(21.6 \%)$ & $169(97.1 \%)$ & & & \\
\hline
\end{tabular}

\section{Discussion}

In this study, most subjects were in their productive age $(87.5 \%)$ which is in line with the finding in a study performed by Balakrishnan in India stating that the productive age or age $\geq 64$ is the age when most people suffer from TB. ${ }^{11}$ Most TB sufferers are male, which may be due to the tendency that men are involved in more outdoor activities compared to women. ${ }^{12}$ Most subjects graduated from senior high school (33.9\%), which is similar to the finding in a previous study stating that most TB patients graduated from senior high school education. ${ }^{13}$

The results of the HbA1c testing presented that $29.8 \%$ or a total of 74 subjects suffered

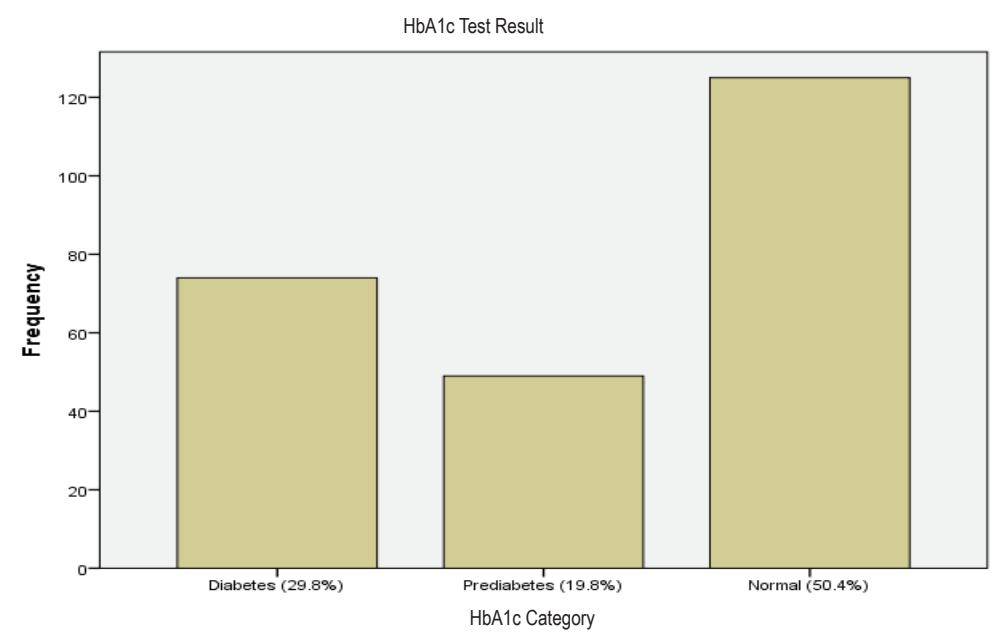

Figure HbA1c Category 
from TB-DM. A study conducted in Jakarta and Bandung regions has suggested that $14.8 \%$ of TB patients are TB-DM patients. ${ }^{14}$ The average HbA1c level in TB-DM patients in the current study was $10.738 \%$, which was 2 (two) times higher than the average HbA1c level in TBNon DM patients of $5.426 \%$. The higher HbA1c level in TB-DM patients is also seen in several previous studies, including a study from India. ${ }^{15}$ The higher HbA1c level in TB-DM patients might be caused by the fact that in TB patients with DM co-infection, the pancreas has experienced damage that the insulin level in patient's body becomes low, leading to a high blood glucose level that correlates with a high level of HbA1c in these patients. ${ }^{4,10}$ In addition, a high level of HbA1c in a TB patient $(\geq 6.5 \%)$ indicates that the TB patient falls into the TB-DM category. This disease combination is very dangerous because it will increase the risk for a TB patient to suffer from active TB by 3 times. This also will worsen TB treatment results, increase the risk of death during TB treatment, a higher recurrence rate after treatment, difficulties in blood glucose control, and even lead to multi-drug resistance. ${ }^{4}$ Treatment for TB-DM patients requires a longer time because both diseases need to be treated and the two treatments may inhibit each other's effect due to drug reactions. Furthermore, diabetes can cause impaired kidney function and also increase the risk of drug poisoning. ${ }^{13} \mathrm{DM}$ is also reported as a predictor of drug types that can damage the liver, increasing the possibility of liver damage when given together with antituberculosis drugs (ATD). ${ }^{16}$ TB-DM patients have a higher risk to become MDR TB patients. ${ }^{8,11}$

Men was dominant among the subjects in this study, including in the TB-DM category $(\mathrm{n}=54,32.3 \%)$. Studies in Indonesia and Brazil stated that male sex is 1.8 times more likely to suffer from tuberculosis. ${ }^{17,18}$ Meanwhile, data on Indonesian health profile shows that the number of TB cases in men is 1.4 times when compared to women. ${ }^{2}$ For Aceh, the number of male TB patients in 2017 was 4,647, which was much higher than the number of female TB patients $(n=2,571)^{2}$ a similar finding in TB-DM was also presented by Balakrishnan et. al. ${ }^{11}$. This phenomenon might be due to the tendency of men to be involved more outdoor activities and to adopt unhealthy lifestyle, including smoking, that can increase the risk of tuberculosis by 2-3 times. ${ }^{12}$ Alcohol consumption also increases the risk. $^{15,19}$

In this study 58 TB patients were diagnosed to have DM by the health care workers; however, the $\mathrm{HbA} 1 \mathrm{c}$ test results showed that there were 16 patients who were not diagnosed as DM patients by the health care workers but had a HbA1c level that are in the category of diabetes (HbA1c level $\geq 6.5 \%$ ). Chi square test showed that DM history has a relationship with HbA1c level ( $p$-value $\leq 0.0001$ ). The risk of people with a history of DM 122 times to have a HBA1c level $\geq 6.5 \%$ compared to people who do not have DM history. The IDF report stated that the number of undiagnosed DM patients in Indonesia is around 6,546-8,185 people or ranked 4th in the world. ${ }^{5}$ It is also reported that in developing countries in Asia region, the prevalence of TB-DM is 1.8-9.5 times higher, making it necessary to do HbA1c screening in TB patients. ${ }^{11,20}$

In conclusion, the need for HbA1c screening of TB patients is obvious in order to prevent the transition from TB to TB DM. This needs to be emphasized by the policy makers because not all TB patients who may have DM are diagnosed by the health care workers in hospitals and public health centers.

\section{References}

1. WHO. Global tuberculosis report. Geneva: World Health Organization; 2018.

2. Kemenkes RI. Profile Kesehatan Indonesia Tahun 2017. Jakarta: Kementerian Kesehatan RI; 2018.

3. Dinkes Aceh. Profil kesehatan Aceh Tahun 2017. Aceh: Dinas Kesehatan Provinsi Aceh; 2018.

4. Kemenkes RI. Konsensus Nasional Tuberkulosis dan Diabetes melitus. Jakarta: Kementerian Kesehatan RI Ditjen P2PL Direktorat P2TM; 2015. Available from: https://pbperkeni.or.id/ wp-content/uploads/2019/01/1.-BukuKonsensus-Nasional-Tuberkulosis-danDiabetesmelitus.pdf

5. IDF. IDF Diabetes Atlas $8^{\text {th }}$ Edition. Brussels, Belgium: International Diabetes Federation, 2017. p. 1-150.

6. WHO. Global report on diabetes. Global Report on Diabetes. France: World Health Organization; 2016. Available from: http:// www.who.int/about/licensing/ copyright_ form/index.html).\%0AThe

7. Riskesdas. Hasil Utama Riskesdas 2018. 2018;88.

8. Chang JT, Dou HY, Yen CL, Wu YH, Huang $\mathrm{RM}$, Lin HJ, et al. Effect of type 2 diabetes mellitus on the clinical severity and 
treatment outcome in patients with pulmonary tuberculosis: A potential role in the emergence of multidrug-resistance. J Formos Med Assoc. 2011;110(6):372-81. Available from: http://dx.doi.org/10.1016/ S0929-6646(11)60055-7.

9. Yuniarti E. Uji Sensitivitas mycobacterium tuberculosis terhadap obat anti tuberkulosis pada penderita tuberkulosis paru dengan diabetes melitus. Sainstek J Sains Teknol. 2019;7(1):51.

10. WHO. Use of glycated haemoglobin (HbA1c) in the diagnosis of diabetes mellitus: abbreviated report of a WHO consultation. Geneva: World Health Organization; 2011.

11. Balakrishnan S, Vijayan S, Nair S, Subramoniapillai J, Mrithyunjayan S, Wilson $\mathrm{N}$, et al. High diabetes prevalence among tuberculosis cases in Kerala, India. PLoS One. 2012;7(10):1-7.

12. Greenaway C, Sandoe A, Vissandjee B, Kitai I, Gruner D, Wobeser W, et al. Tuberculosis: evidence review for newly arriving immigrants and refugees. CMAJ. 2011;183(12):E939-51.

13. Yanti Z. Pengaruh diabetes melitus terhadap keberhasilan. J Berk Epidemiol. 2017;5:16373.

14. Alisjahbana B, Sahiratmadja E, Nelwan EJ, Purwa AM, Ahmad Y, Ottenhoff THM, et al. The effect of type 2 diabetes mellitus on the presentation and treatment response of pulmonary tuberculosis. Clin Infect Dis.
2007;45(4):428-35.

15. Kumpatla S, Selvam JM, Chinnasamy C, Srinivasan R, Kapur A, Rajan R, et al. Prevalence of diabetes and pre-diabetes and associated risk factors among tuberculosis patients in India. PLoS One. 2012;7(7):e41367.

16. Baghaei P, Marjani M, Javanmard P, Tabarsi P, Masjedi MR. Diabetes mellitus and tuberculosis facts and controversies. J Diabetes Metab Disord. 2013;12(1):1-8.

17. Budi IS, Ardillah Y, Sari IP, Septiawati D. Analisis Faktor Risiko Kejadian penyakit Tuberculosis Bagi Masyarakat Daerah Kumuh Kota Palembang. J Kesehat Lingkung Indones. 2018;17(2):87.

18. Stevens H, Ximenes RA, Dantas OM, Rodrigues LC. Risk factors for tuberculosis in older children and adolescents: a matched case-control study in Recife, Brazil. Emerg Themes Epidemiol. 2014;11(1):-7.

19. Nhamoyebonde S, Leslie A. Biological differences between the sexes and susceptibility to tuberculosis. J Infect Dis. 2014;209(Suppl 3):S100-6.

20. Zheng $\mathrm{C}, \mathrm{Hu} \mathrm{M}$, Gao F. Diabetes and pulmonary tuberculosis: A global overview with special focus on the situation in Asian countries with high TB-DM burden. Glob Health Action. 2017;10(1):1-11. Available from: http://dx.doi.org/10.1080/16549716 .2016 .1264702 